
N
857.5
A84
1962
MRC 

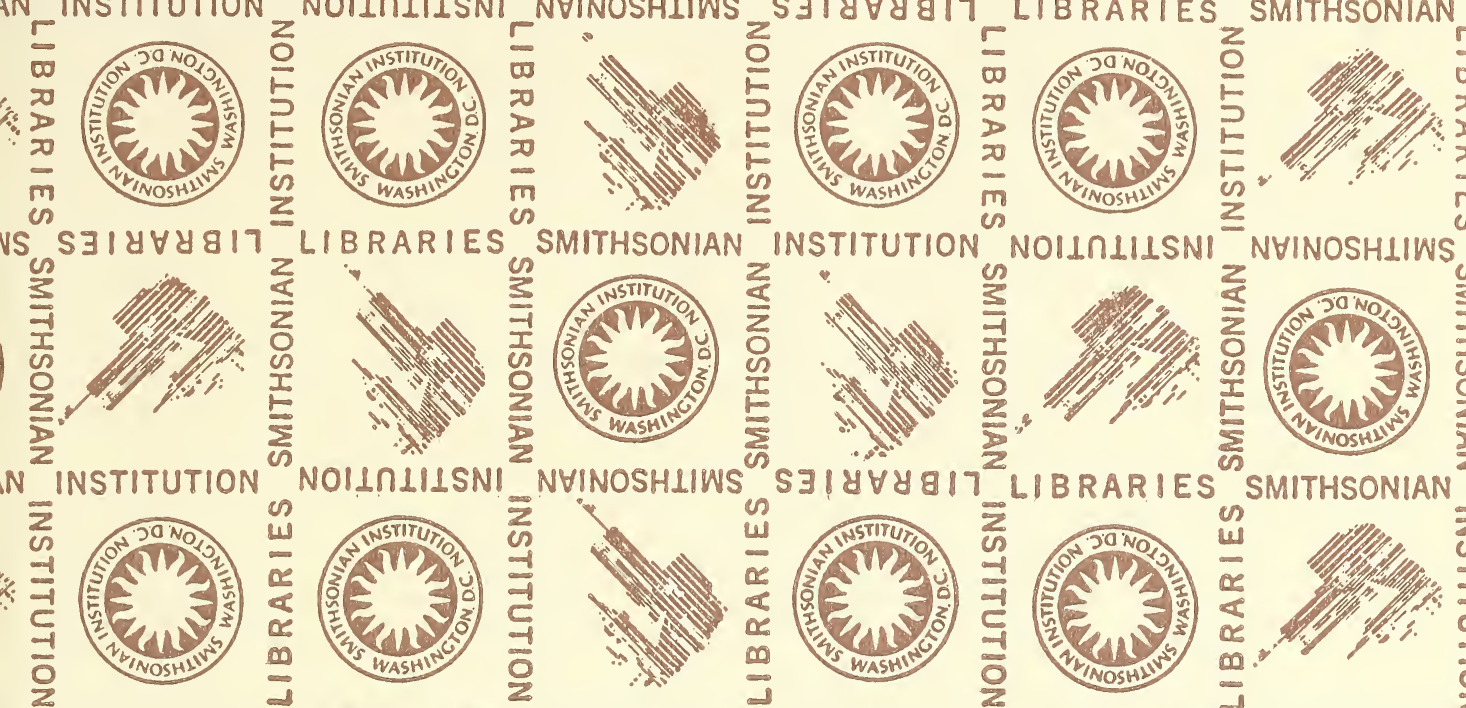

IS S3IY甘8817 LIBRARIES
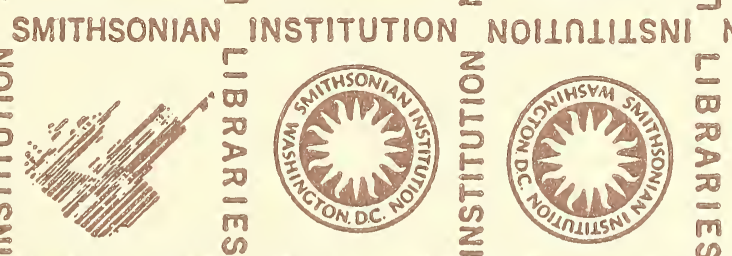

NYINOSHLIWS
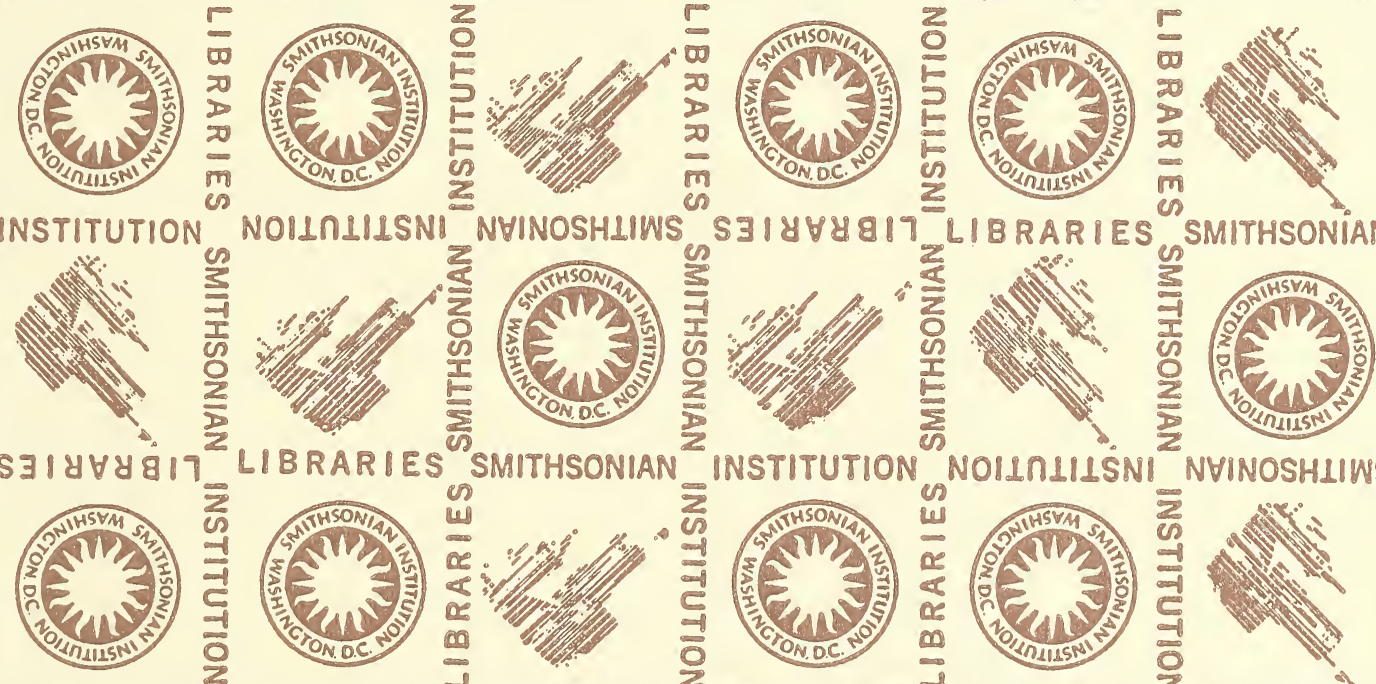

INSTITUTION NOIINLILSNI NHINOSHIIWS
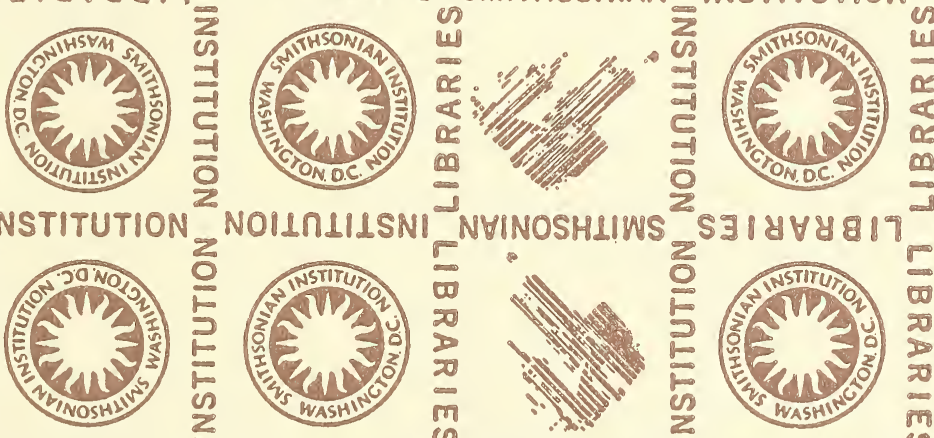

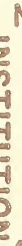

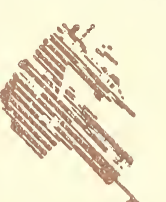

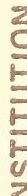
0
3
3
0
0
0
2
$\frac{1}{2}$

MITHSONIAN
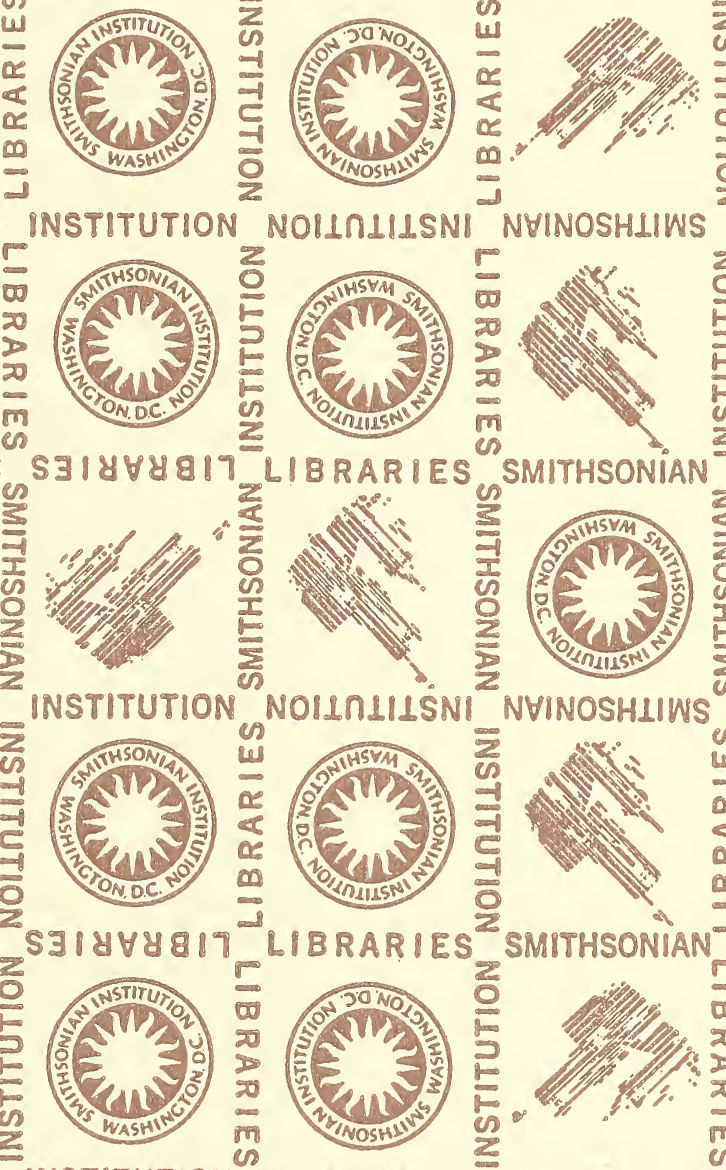

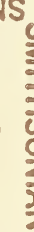

LIBRARIES SMITHSONIAN
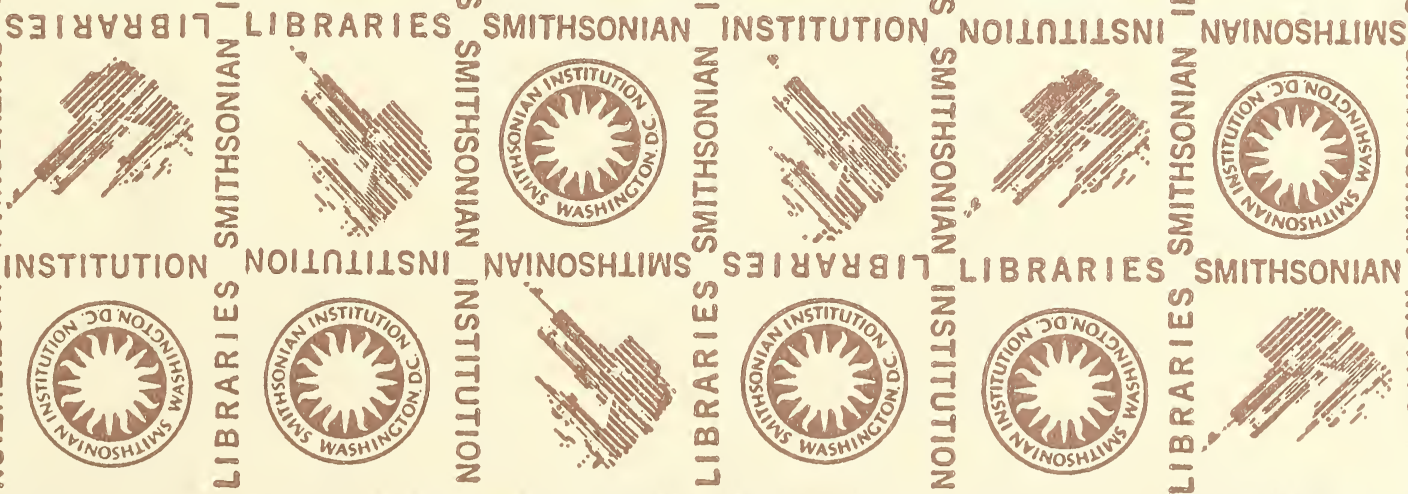

S S3IYUY8IT LIBRARIES

SMITHSONIAN 

SI-Pubno.

4504

SI-CIIC.

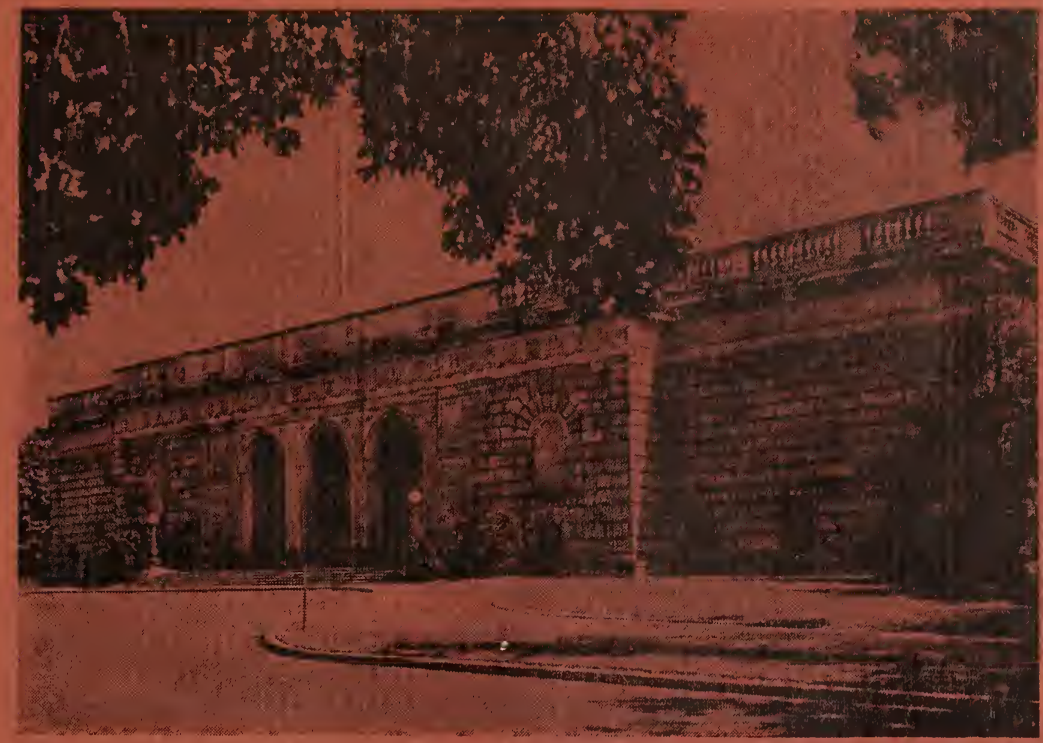

\section{The Freer Gallery of Art of the}

\section{SMITHSONIAN INSTITUTION}

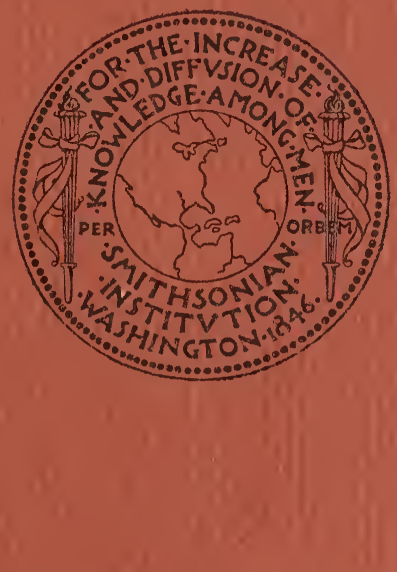

WASHINGTON, D. C. 


\section{PORT CITY PRESS, INC.}

BALTIMORE, MD., U. S. A.

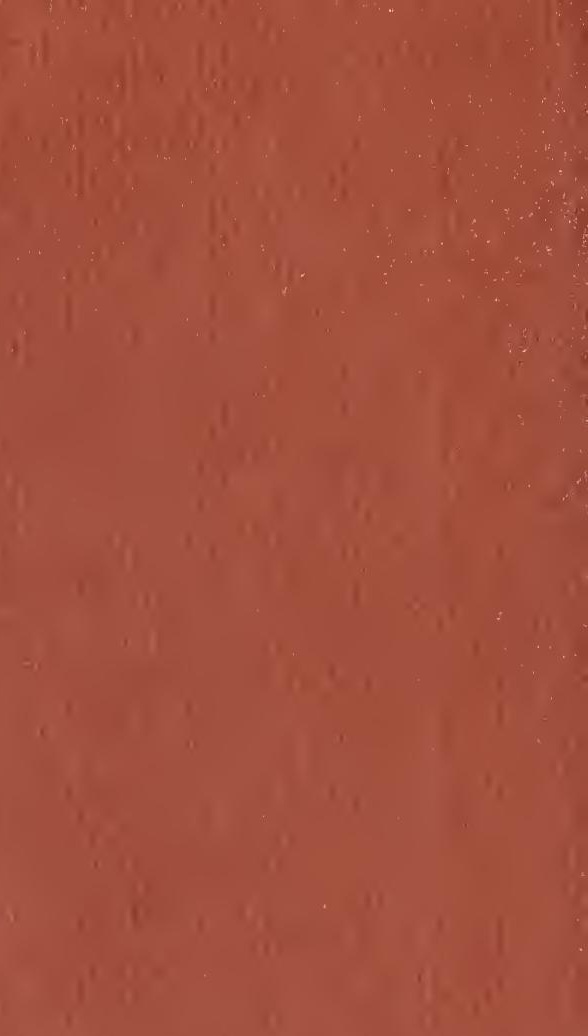




\section{SMITHSONIAN INSTITUTION}

\section{OCT $19198 ?$ \\ LIBRARIES}

\section{THE FREER GALLERY OF ART}

\section{THE FOUNDATION}

The Freer Gallery of Art, the Freer Collection, and an endowment fund to provide for the study and acquisition of Oriental fine arts were given in trust to the Smithsonian Institution by Charles L. Freer, of Detroit. The formal deed of gift was executed on May 5, 1906, during the administration of President Theodore Roosevelt. Under the terms of this deed, Mr. Freer retained the right to keep the collection in his possession during his lifetime and to make additions to it, although it was understood that an object once incorporated in the collection should not be removed from it. After his death the collection was to be removed to Washington and placed in a building given by the founder, designed in accordance with his wishes and erected within the grounds of the Smithsonian Institution. In accepting this gift the Government agreed to care for and maintain the building and collections at public expense. In addition to these provisions Mr. Freer created an endowment fund, the income from which was to be used "for the study of the civilization of the Far East," for additions to his Oriental collections, and for certain other specified activities and developments that he wished to have carried on after his death, independently, if need be, of Congressional appropriation. Loans to or from the collection, or additions to it by gift, were forbidden by the terms of the deed of gift.

\section{THE FOUNDER}

Charles L. Freer was born at Kingston, N. Y., on February 25, 1856, the son of Jacob R. and Phoebe Jane (Townsend) Freerof French-Huguenot ancestry. His first American ancestor was one of the original patentees of New Paltz, N. Y.

As a boy of 14, after having attended public school, he went to work in a cement factory in his neighborhood. At 16 he was a clerk in the general store of John C. Brodhead at Kingston. In the same building with the store were the offices of the New York, Kingston, \& Syracuse Railroad of which Col. Frank J. Hecker was the superintendent. The latter was attracted by the 
ability of the young clerk and in 1873 took him into his employ, thus beginning an association that was to endure for life. After several years of railroad work Charles Freer went with Colonel Hecker to Detroit, where, in 1880, he took part in the organization of the Peninsular Car Works and became assistant treasurer. Between 1880 and $1900 \mathrm{Mr}$. Freer was associated with this company and those which succeeded it. In 1900, after completing his work in the merger with the American Car \& Foundry Co., he retired from active business.

After 1900 to the end of his life, Mr. Freer devoted the greater part of his time and interest to the study and development of his art collections, begun during the early eighties.

His first field of acquisition was that of etchings and lithographs. Among the earliest objects in the present collection is the set of Whistler etchings, "Venice, Second Series," bought in 1887. A brief period of interest in Japanese prints led to the older arts of Japan-screen paintings and pottery-and these, in their turn, to the classic arts of China. During this period of his life, Mr. Freer made frequent trips to Europe and the Orient, visiting Egypt, India, Ceylon, Java, China, and Japan.

As a collector, Charles Freer possessed a sensitive and discriminating taste that stood him in good stead as he adventured among the fine arts of the classic antiquity of China, just beginning to be seen by Western eyes. His generous provision for future acquisitions and for serious study in this field was significant of his recognition of its importance to scholarship as well as to esthetics. No scholar himself, he had a sincere and deep regard for truth, for right proportion and exact understanding of the fine arts. His gift was appropriately placed in the care of the Smithsonian Institution, whose seal is inscribed with the words: "For the increase and diffusion of knowledge among men." Mr. Freer died in New York City on September 25, 1919.

\section{THE BUILDING}

The building, which stands on the south side of the Mall, on Jefferson Drive at Twelfth Street, SW., west of the main building of the Smithsonian Institution, is constructed of Stony Creek granite, in the style of Florentine Renaissance palace architecture. The architect was Charles A. Platt, of New York. Ground was broken on September 23, 1916, in the presence of officials of the Smithsonian Institution. The building was completed in the spring of 1921, about 18 months after the death of the founder. The opening of the Freer Gallery of Art took place on May 2, 1923. 


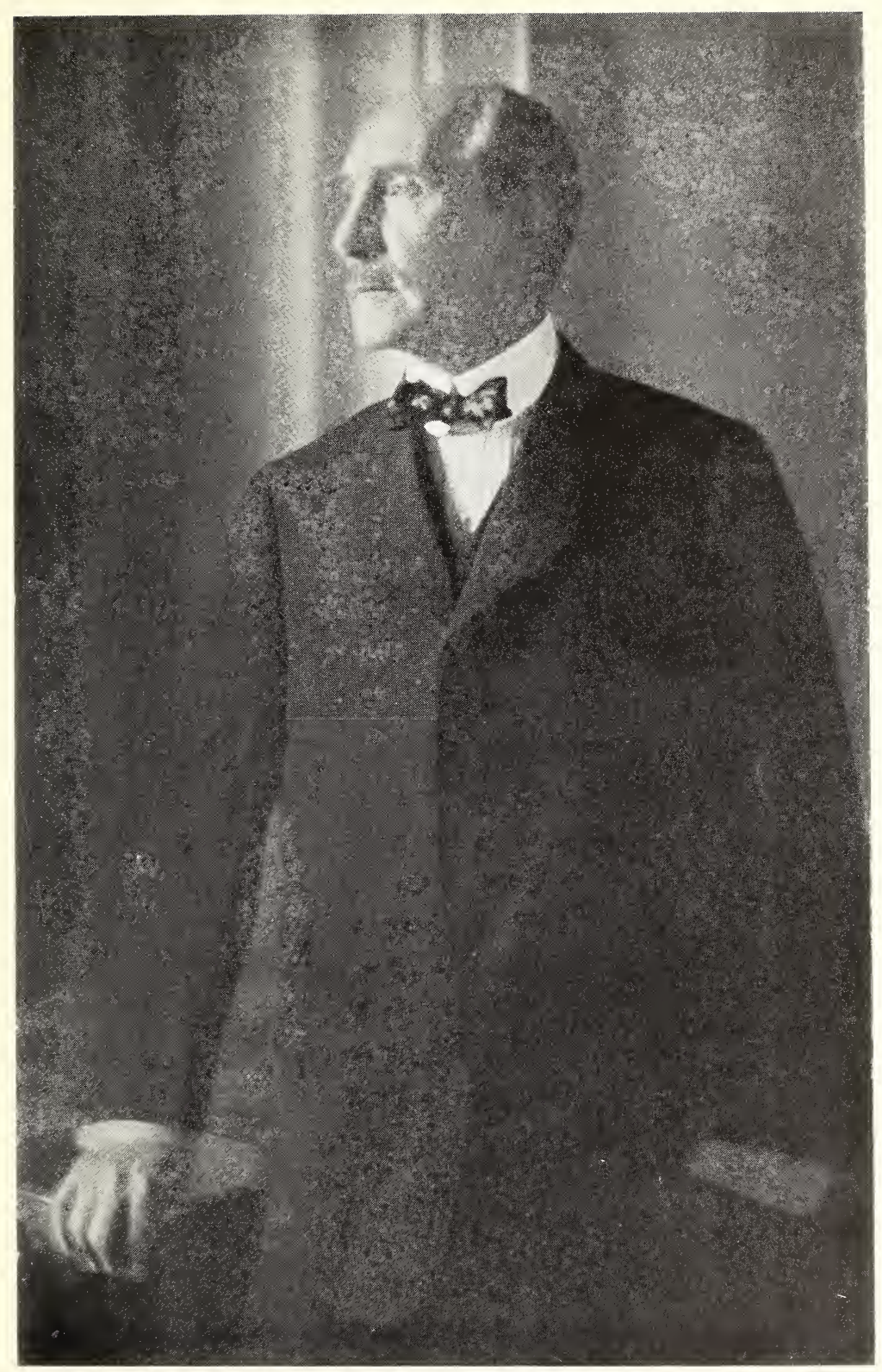

Charles Lang Freer, 1856-1919. 
The building has two main floors. The upper floor, which contains 18 top-lighted exhibition galleries and Whistler's Peacock Room, surrounds a garden court open to the sky. This court is faced with Tennessee white marble. The lower floor at ground level contains offices, study and storage rooms, library, photographic laboratory, technical laboratory, workshops, and an auditorium.

\section{THE COLLECTIONS}

The Oriental collections include works of art from the Far East-China, Japan, Korea, and Tibet; from India and IndoChina; and from the Near East-Iran (Persia), Iraq, Syria, Asia Minor, Byzantium, and Egypt. These collections have been continuously and importantly augmented by purchase since the completion of the Freer Gallery in 1921. From these growing collections, with changes made from time to time, a selected exhibition is made. Briefly summarized, the collections are as follows:

CHinA: Bronze, jade, sculpture, painting, lacquer, pottery, and porcelain.

JAPAN: Sculpture, painting, lacquer, pottery, and porcelain.

KOREA: Pottery and bronze.

INDIA: Sculpture, manuscripts, and painting.

IRAN (PERSIA): Manuscripts, metalwork, painting, pottery, and sculpture.

EGYPT AND SYRIA: Sculpture, manuscripts, glass, and metalwork. Greek, Aramaic, and Armenian Biblical manuscripts, early Christian painting, gold, and crystal. The outstanding objects in this group are the fourth-fifth century manuscript of the Gospel according to the four Evangelists, and a thirdcentury Greek (Egypt) papyrus manuscript of The Minor Prophets (in part) known respectively as Washington Manuscripts Nos. III and V.

The arts of the West are represented by the collection of works by James McNeill Whistler, which include a great number of oils, water colors, pastels, drawings, etchings, lithographs, and the Peacock Room; paintings by George deForest Brush, Thomas Wilmer Dewing, Childe Hassam, Winslow Homer, Gari Melchers, Willard Leroy Metcalf, John Francis Murphy, Charles Adams Platt, Albert Pinkham Ryder, John Singer Sargent, Joseph Lindon Smith, Abbott Handerson Thayer, Dwight William Tryon, and John Henry Twachtman; two sculptures by Augustus 


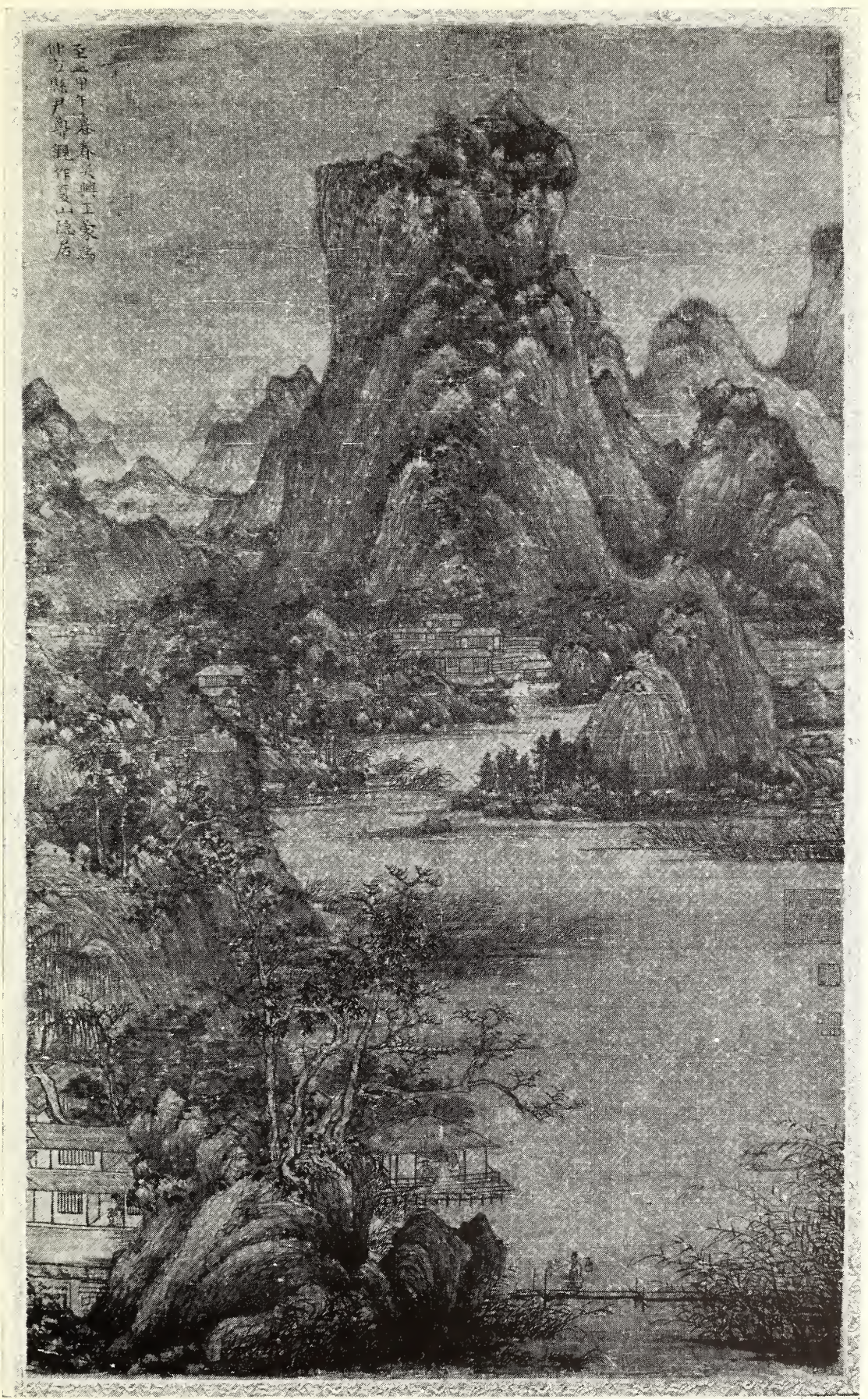

59.17 "Secluded Dwellings in Summer Mountains" by Wang Meng. Chinese, Yüan dynasty, A. D. 1354. 
St. Gaudens, and a group of Pewabic pottery by Mary Chase Perry Stratton. By the terms of the Foundation, the section of American arts is closed against further accessions.

\section{THE LIBRARY}

The library, on the ground floor, is available to readers during office hours, from 9 A.M. to 4:30 P.M. daily, from Monday through Friday. It contains over 34,450 books, pamphlets, and periodicals, approximately 18,600 of which are in Chinese and 2,000 in Japanese, devoted to subjects represented in the collection, namely, the arts and culture of the Far East, India, and the Near East; Biblical manuscripts; and the life and works of James $\mathrm{McNeill}$ Whistler and other American painters listed on page 4. These publications are for use inside the building only.

\section{PUBLICATIONS}

A list of Freer Gallery of Art publications with prices will be furnished upon request.

\section{REPRODUCTIONS}

Most of the important objects in the collection have been photographed, and prints can be supplied in black-and-white at prices determined by their size. The Gallery maintains a sales desk to supply these at approximately cost price. The most satisfactory method of selection is to consult the albums of sample photographs on file at this desk. When this is impossible, it is suggested that purchasers write to the Gallery.

Certain objects in the collection have been reproduced in the round and others printed by the collotype process. A list of these subjects and prices will be furnished upon request.

The Gallery maintains a file of color and black-and-white slides which are for sale or may be borrowed by institutions or accredited individuals. Information and prices may be had upon request.

\section{POST CARDS}

A selection of post cards in black-and-white and a limited number in color is available. A list of these subjects and prices will be furnished upon request. 


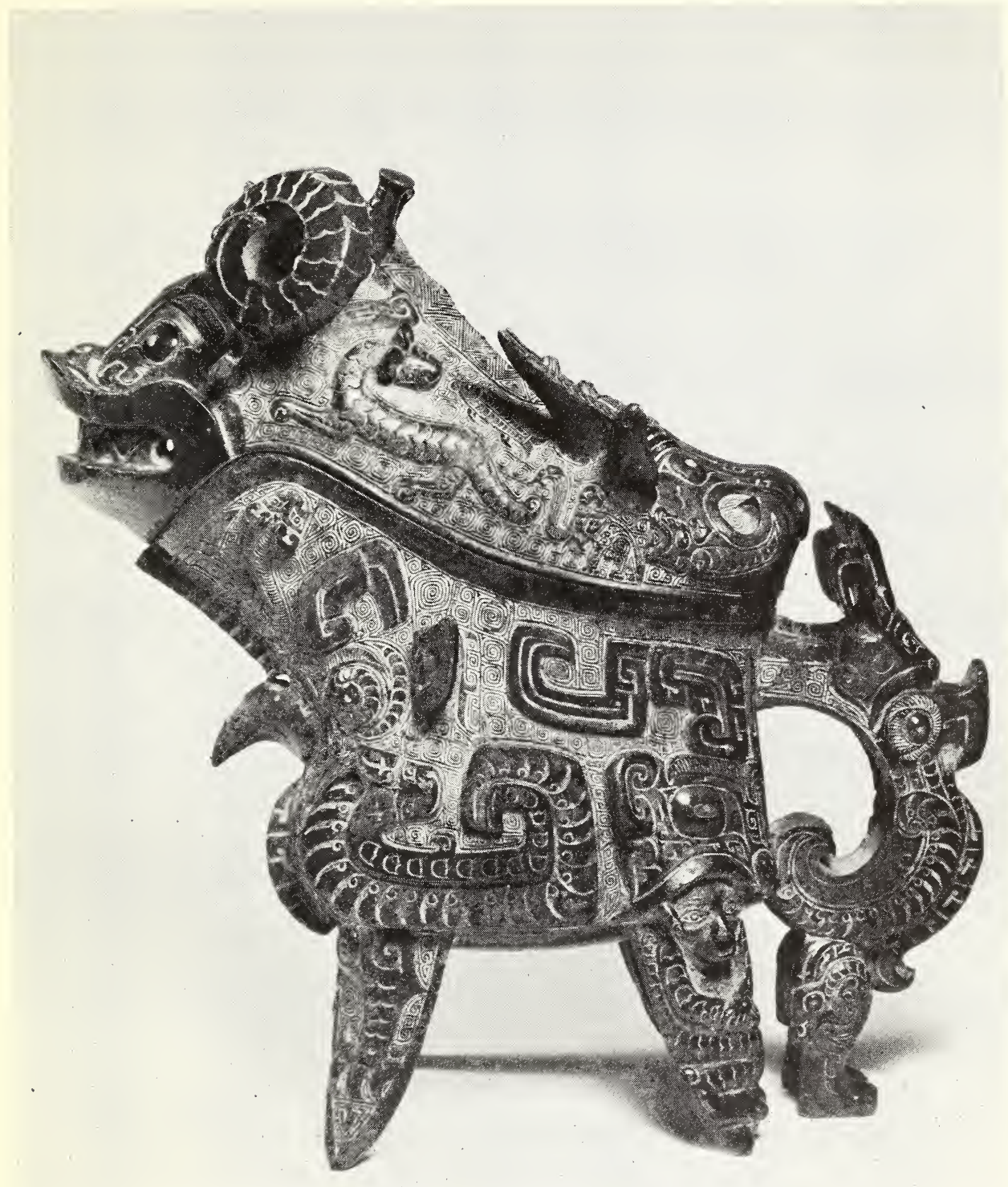

61.33 Bronze ceremonial vessel of the type kuang. Chinese, Shang dynasty, ca. 11 th century B. C. 


\section{USE OF THE BUILDING AND COLLECTIONS}

Admission free.

The Gallery is open every day, including Sunday, from 9 A.M. until 4:30 P.M. It is closed on Christmas Day.

For the convenience of those who desire to pursue work among the objects in the collections, or to study the related cultures, adequate provision has been made. Only a limited number of objects from among the more than 10,000 comprising the collection are shown at any one time in the exhibition galleries, but all are available for the use of students during office hours, from Monday through Friday.

Application for permission to copy objects in the galleries, to photograph with tripod and flash, or to see objects not on exhibition should be made at the administration office situated in the eastern end of the building and reached by the east stairway downward from the entrance lobby.

Portable stools for use in the galleries may be had by applying to a guard.

A wheelchair may be had on application to the guard at the north entrance.

Umbrellas, canes, packages, and baggage must be checked at the entrance. 


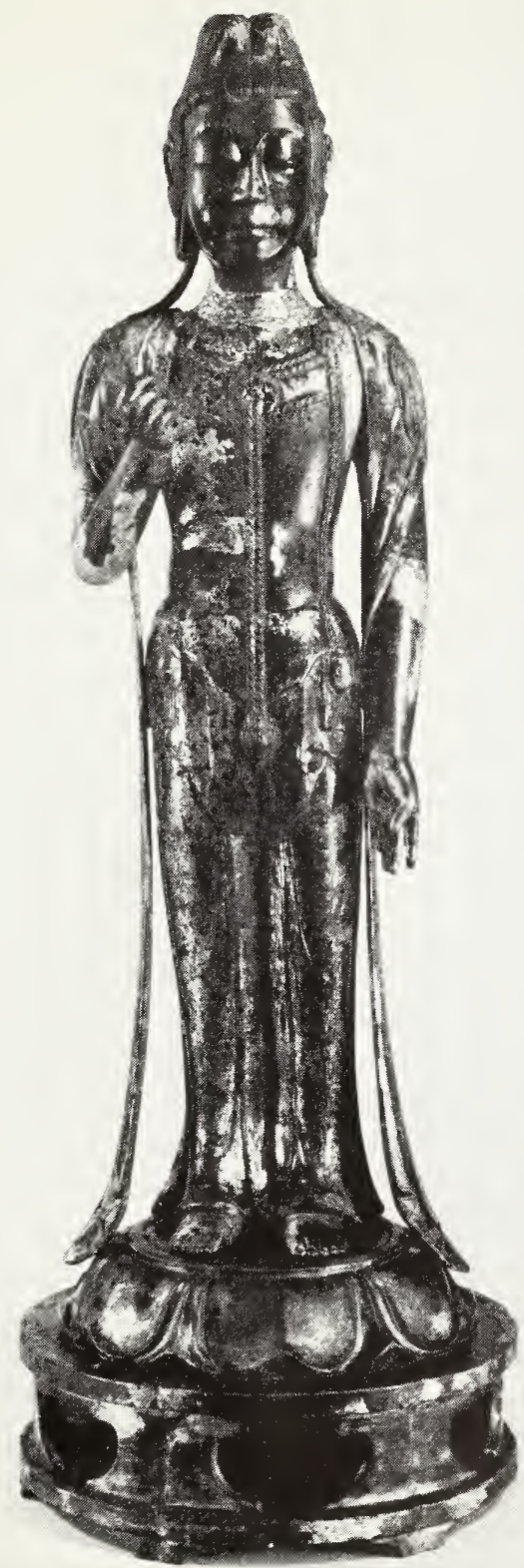

09.343 A Bodhisattva, wood sculpture with lacquer and gilding. Japanese, Suiko period, A. D. 552-645. 


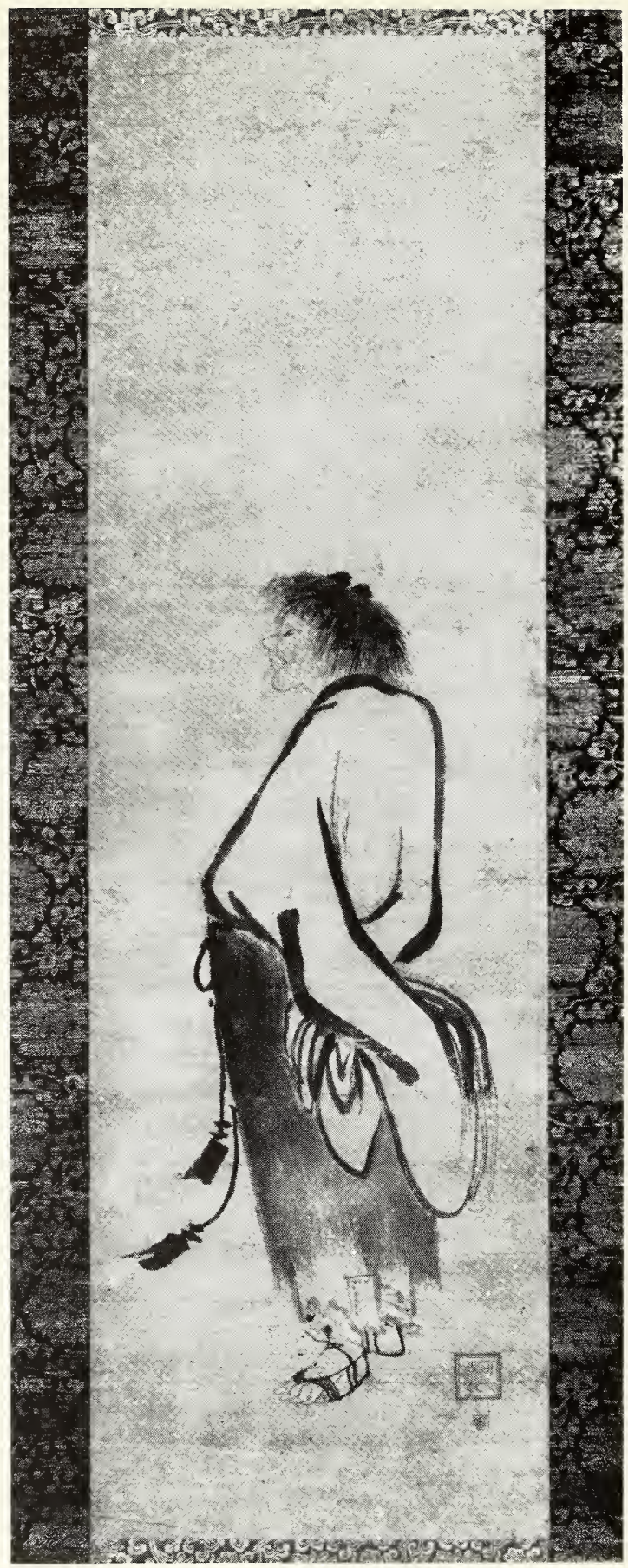

60.23 The Monk Kanzan. Ink painting by Kao. Japanese, Kamakura period, 14th century A. D. 


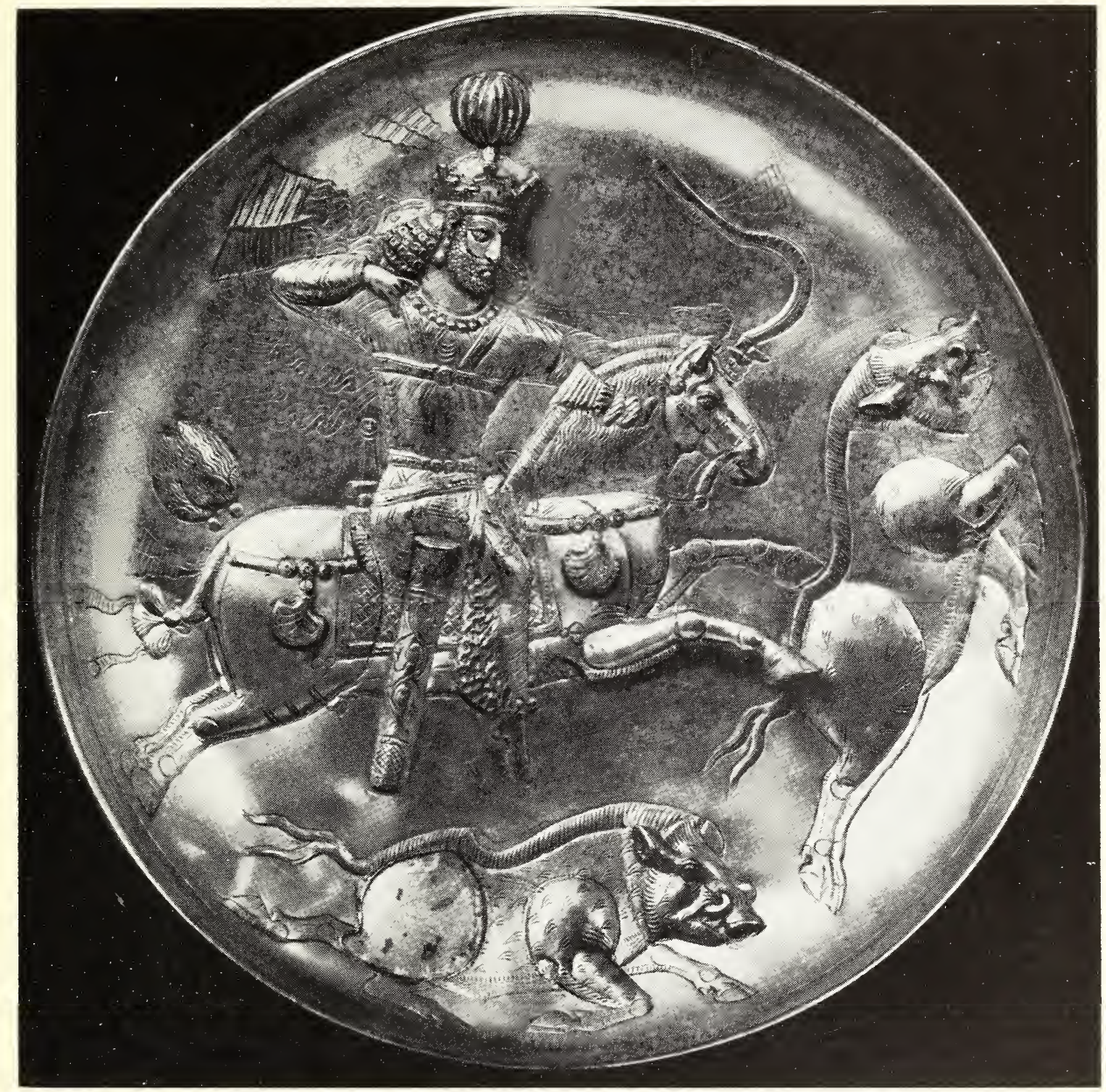

34.23 Silver dish decorated in relief and gilded. Persian, Sāsanian period, fourth century A. D. 


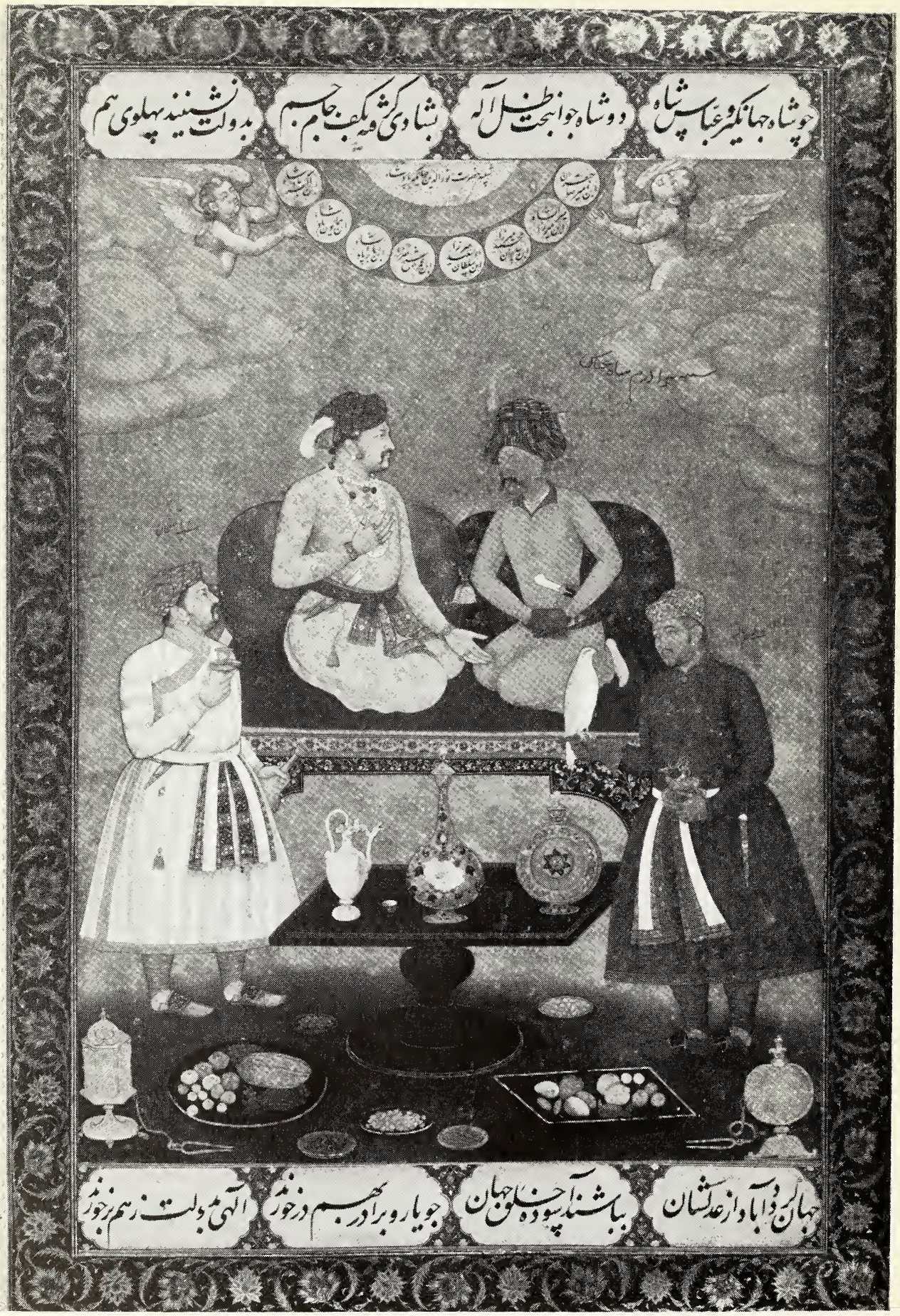

42.16 Imaginary Entertainment of Shāh 'Abbās I by the Emperor Jahāngīr. Indian, Mughal, 17th century A. D. 

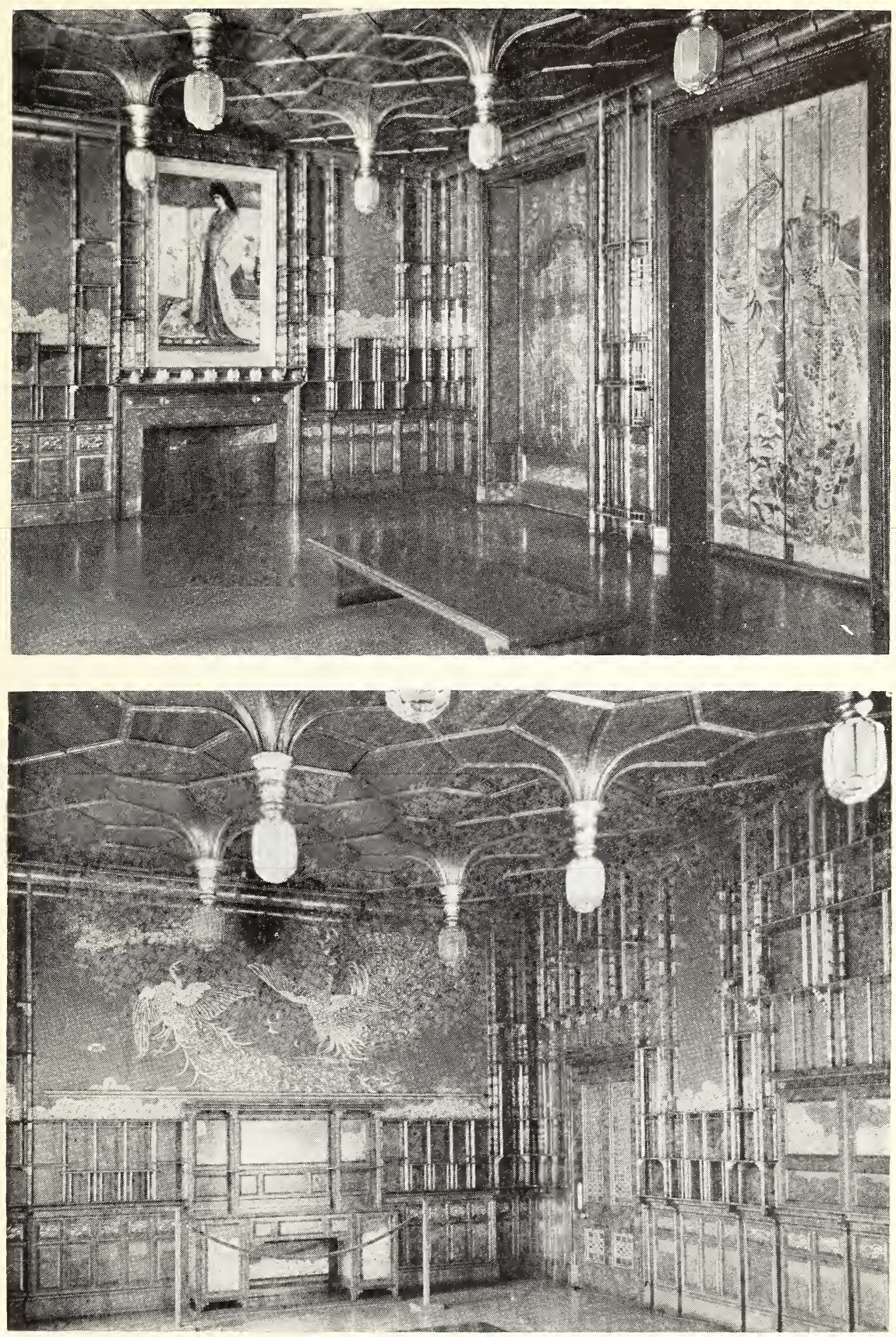

The Peacock Room.

Upper, northeast corner; lower, southwest corner. 


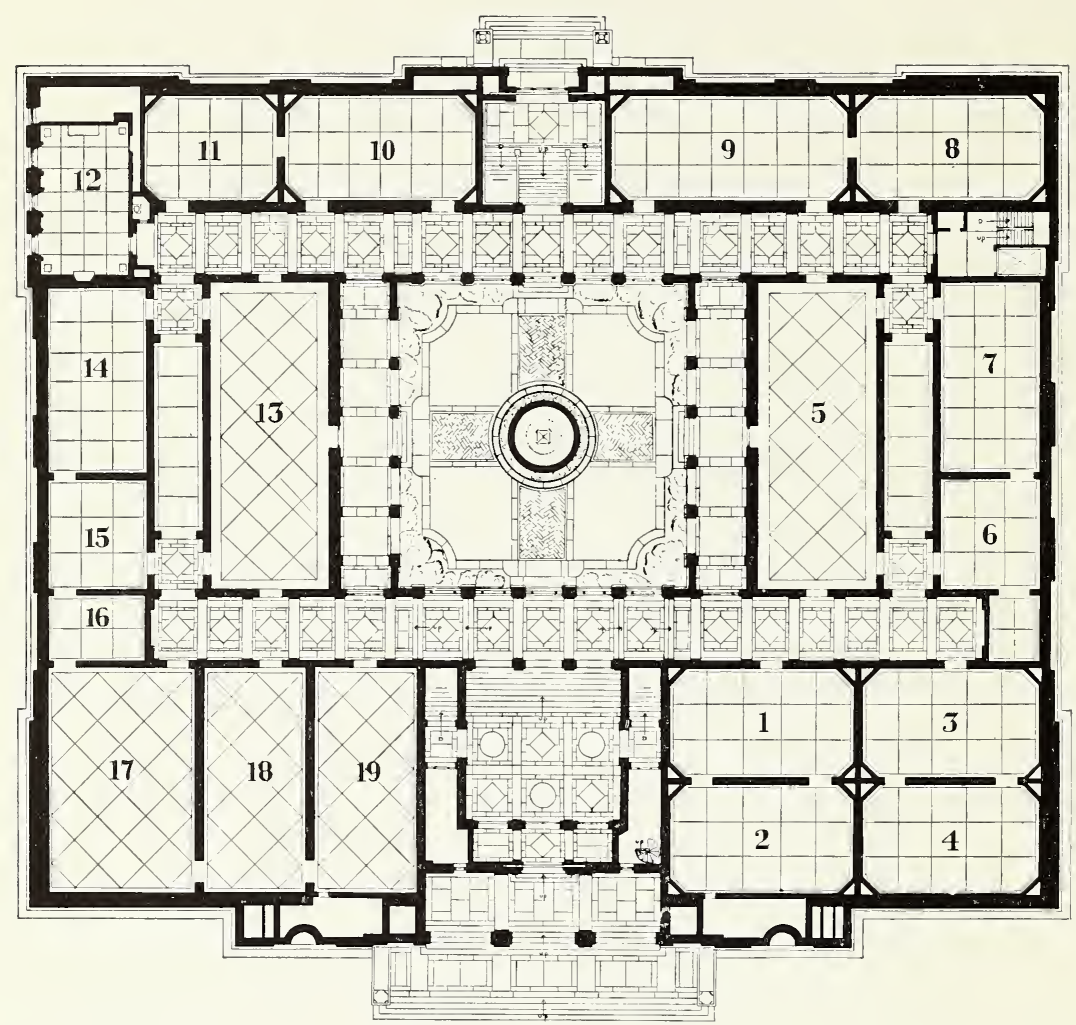

FIRST FLOOR PLAN

\section{SCALE $\overbrace{1.10}^{10} 20 \quad 30 \quad 40 \quad 50$}

The Peacock Room (Gallery 12) and the Chinese sculpture (Gallery 17) are permanent exhibitions. Exhibitions in the other galleries are subject to occasional changes. 


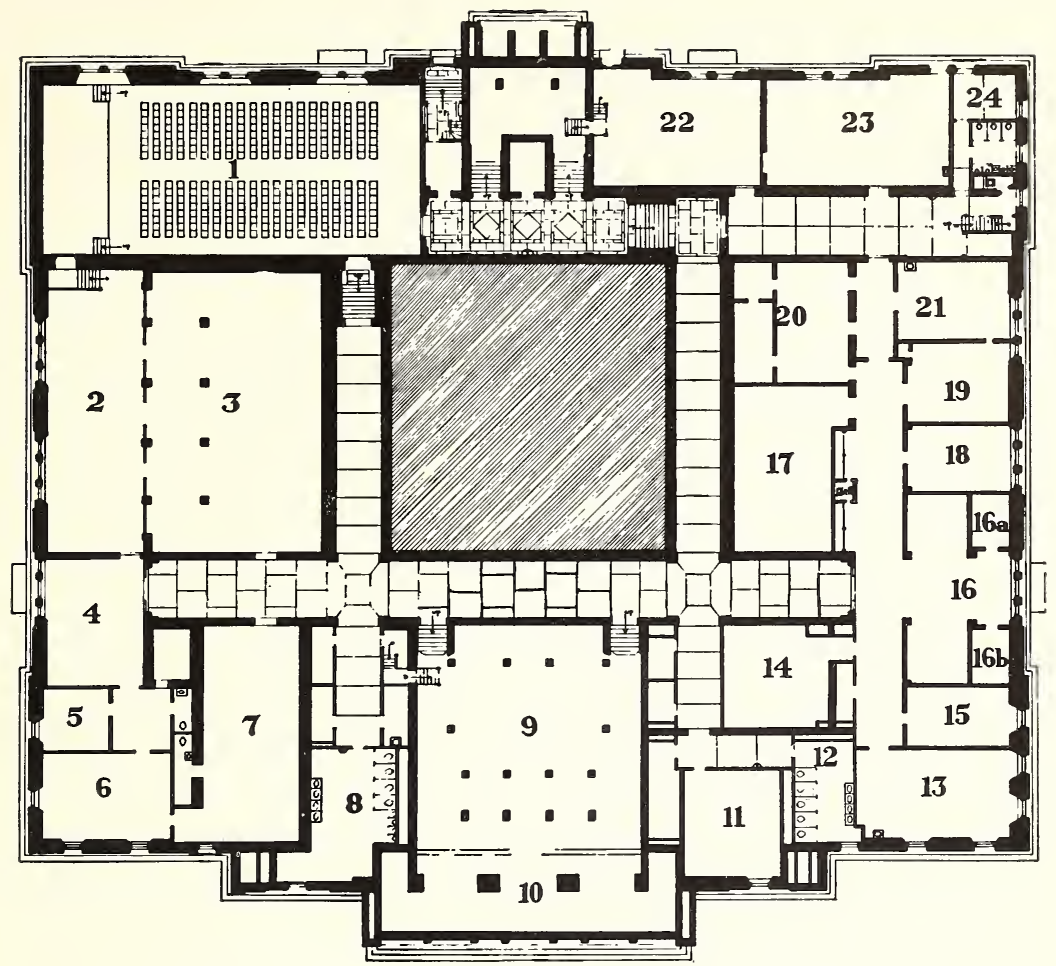

BASEMENT PLAN

SCALE

1. Auditorium

2. Library

3. Storage room

4. Main office

5. Assistant Director's office

6. Director's office

7. Storage room

8. Men's lavatory

9. Fan room

10. Air chamber

11. Staff room

12. Women's lavatory

13. Work room

14. Storage room
15. Office
16. Exhibition storage
16a. Closet
16b. Closet
17. Storage room
18. Office
19. Technical laboratory
20. Photographic laboratory
21. Paint shop
22. Receiving room
23. Cabinet shop
24. Superintendent's office




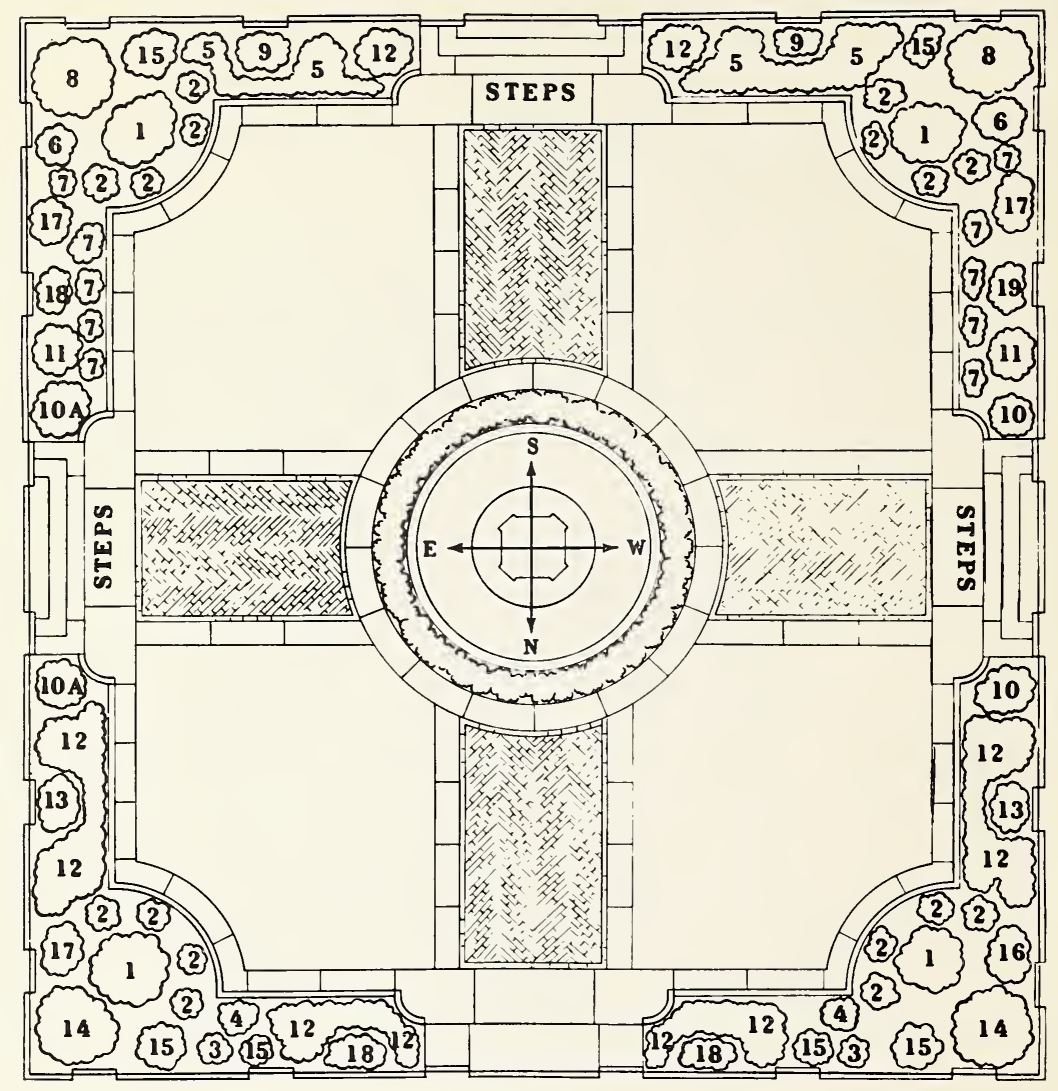

\section{COURT PLANTING}

SCALE نㄴ

1. Buxus sempervirens-Lynnhaven type.

2. Buxus sempervirens-var. suffruticosa.

3. Wistaria sinensis-Chinese wistaria.

4. Ilex aquifolium.

5. Azalea obtusa-Japanese azalea.

6. Viburnum rhytidophyllumLeather leaf.

7. Ilex crenata-var. helleri

8. Ilex opaca-American holly.

9. Ilex crenata.

10. Ilex crenata-var. microphylla.

10a. Ilex crenata-var. latifolia.

11. Ilex crenata-var. rotundifolia.

12. Ilex crenata-var. convexa.

13. Ilex cornuta-var. burfordii.

14. Osmanthus ilicifolius.

15. Mahonia bealei.

16. Ilex crenata-var. rotundifolia.

17. Ilex crenata-var. globosa.

18. Camellia japonica.

19. Camellia reticulata.

Cover planting-Pachysandra terminalis.

Four squares of Meyer zoysia grass.

Space around pool for planting seasonal flowers. 


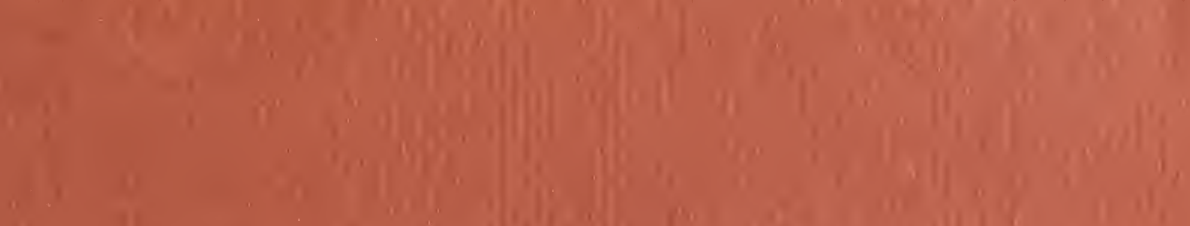
2. a.

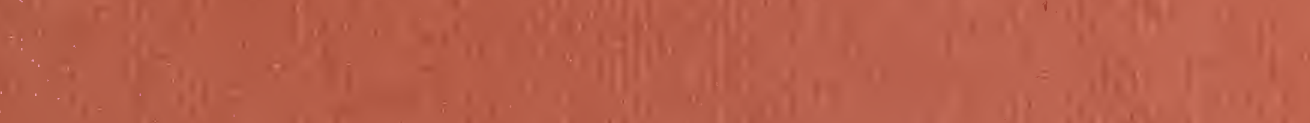
(kin

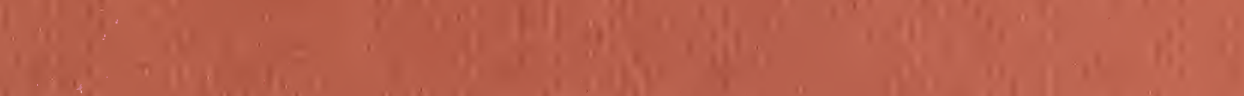
$\therefore=5$. I, 1.

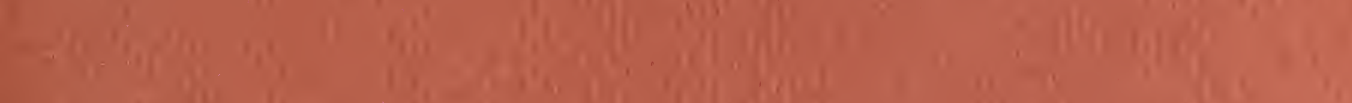

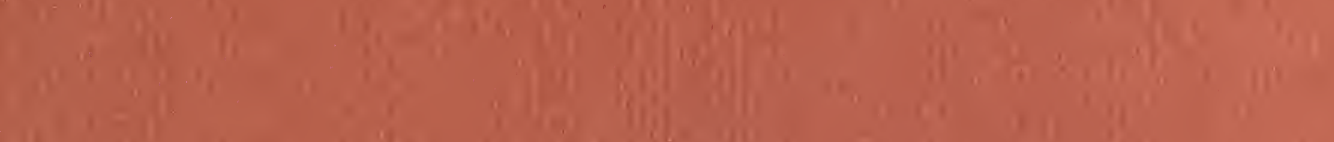

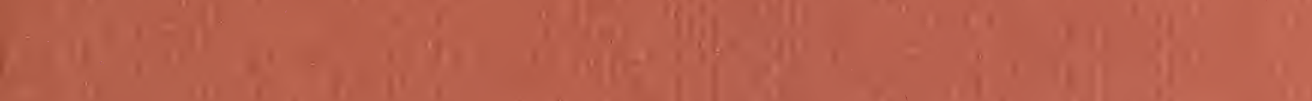

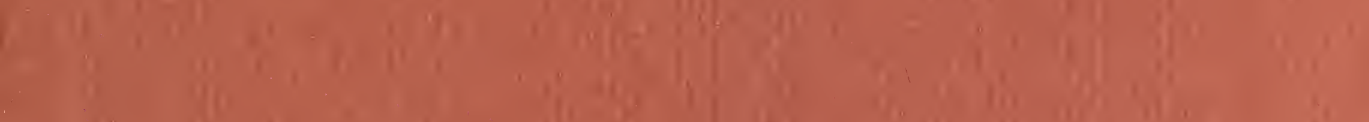

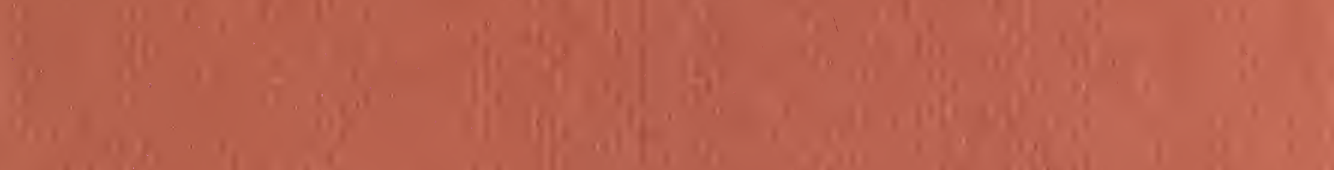

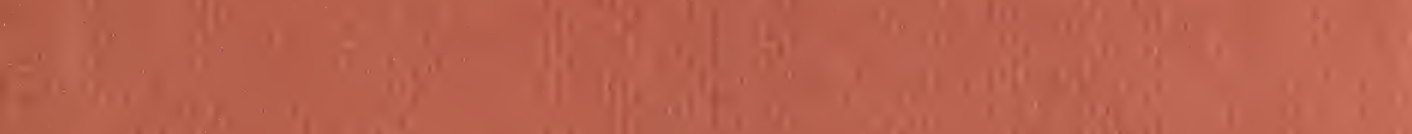
to.

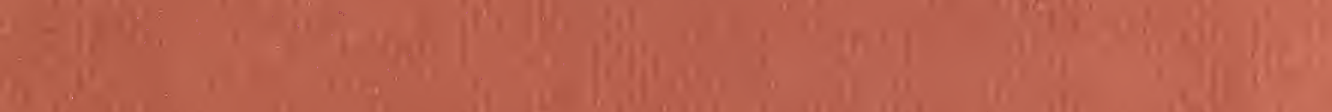
ar,

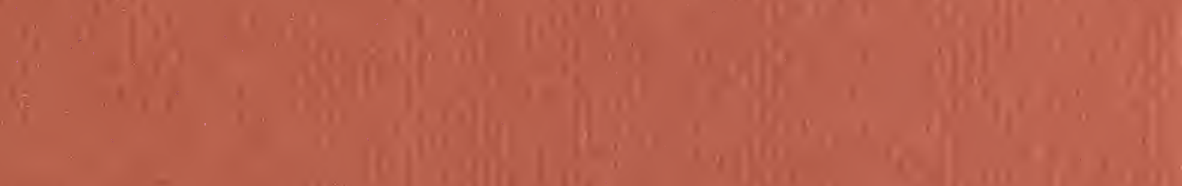

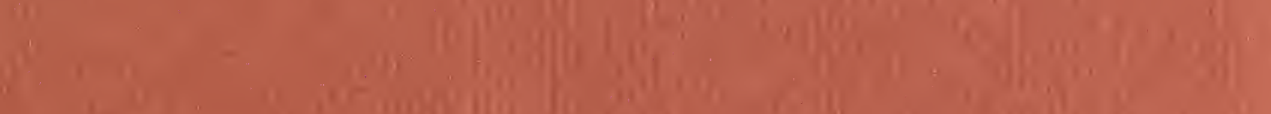

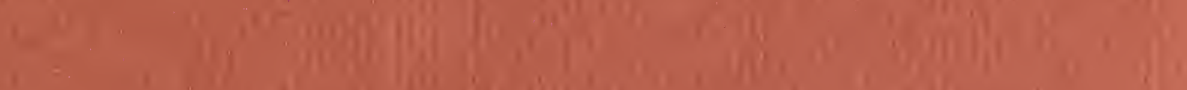

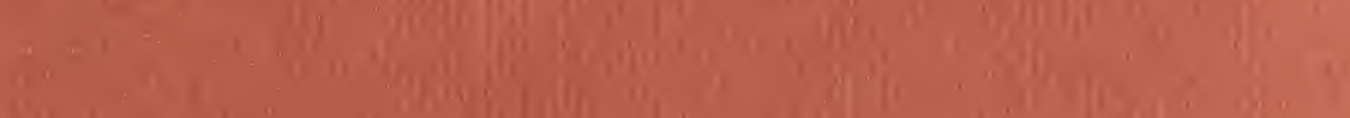

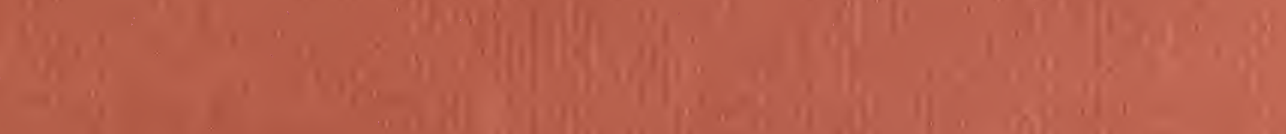

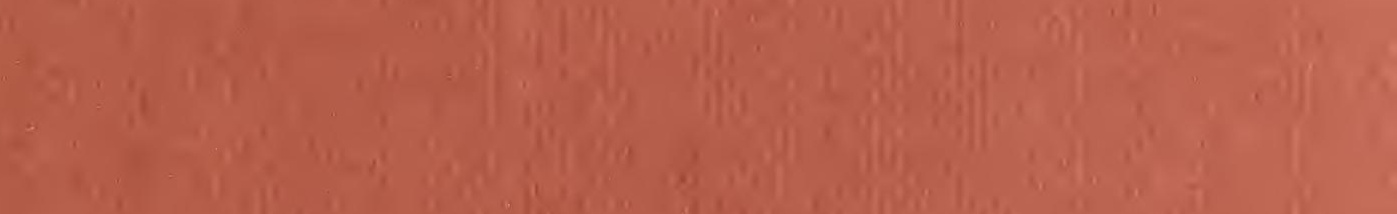
to,

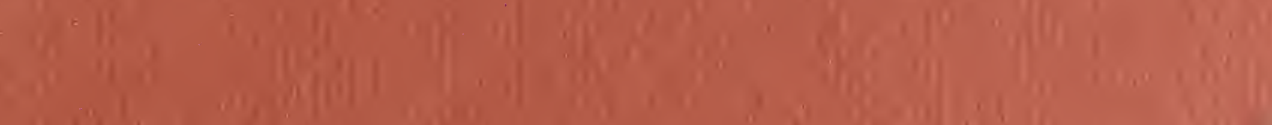

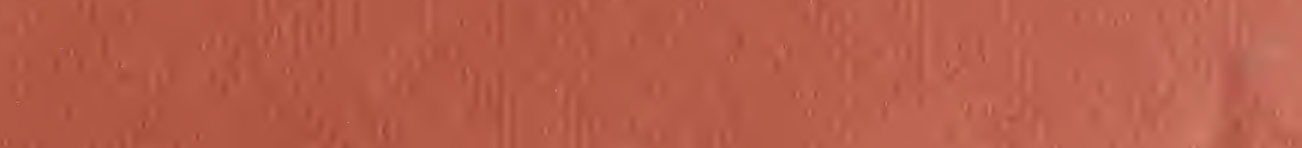


SMITHSONIAN INSTITUTION LIBRARIES

||||||||||||||||||||||||||||||||||||||||||||||||||||||||||||||||||

$\begin{array}{llll}3 & 9088 & 00727 & 8203\end{array}$

$\infty$ 



\section{$\bar{z}$

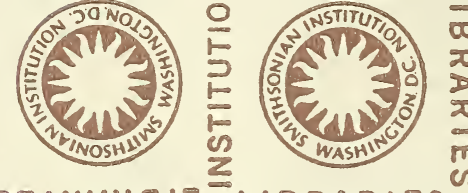

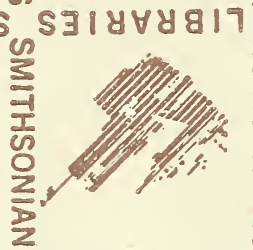
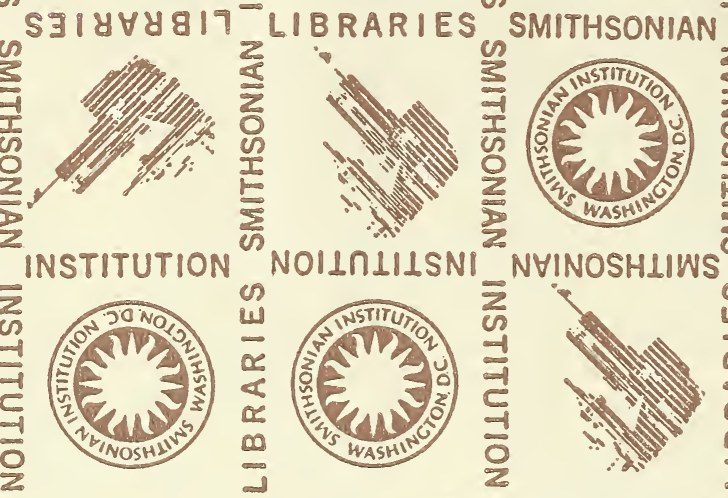

LIBRARIES SMITHSONIAN
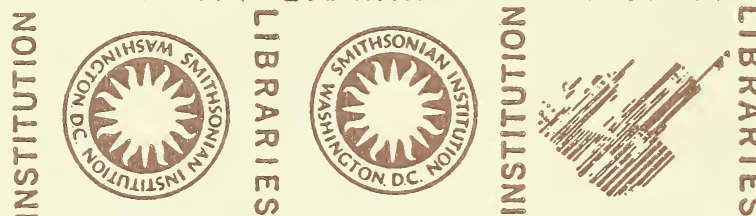

NOILRLIISNI NVINOSHLIWS
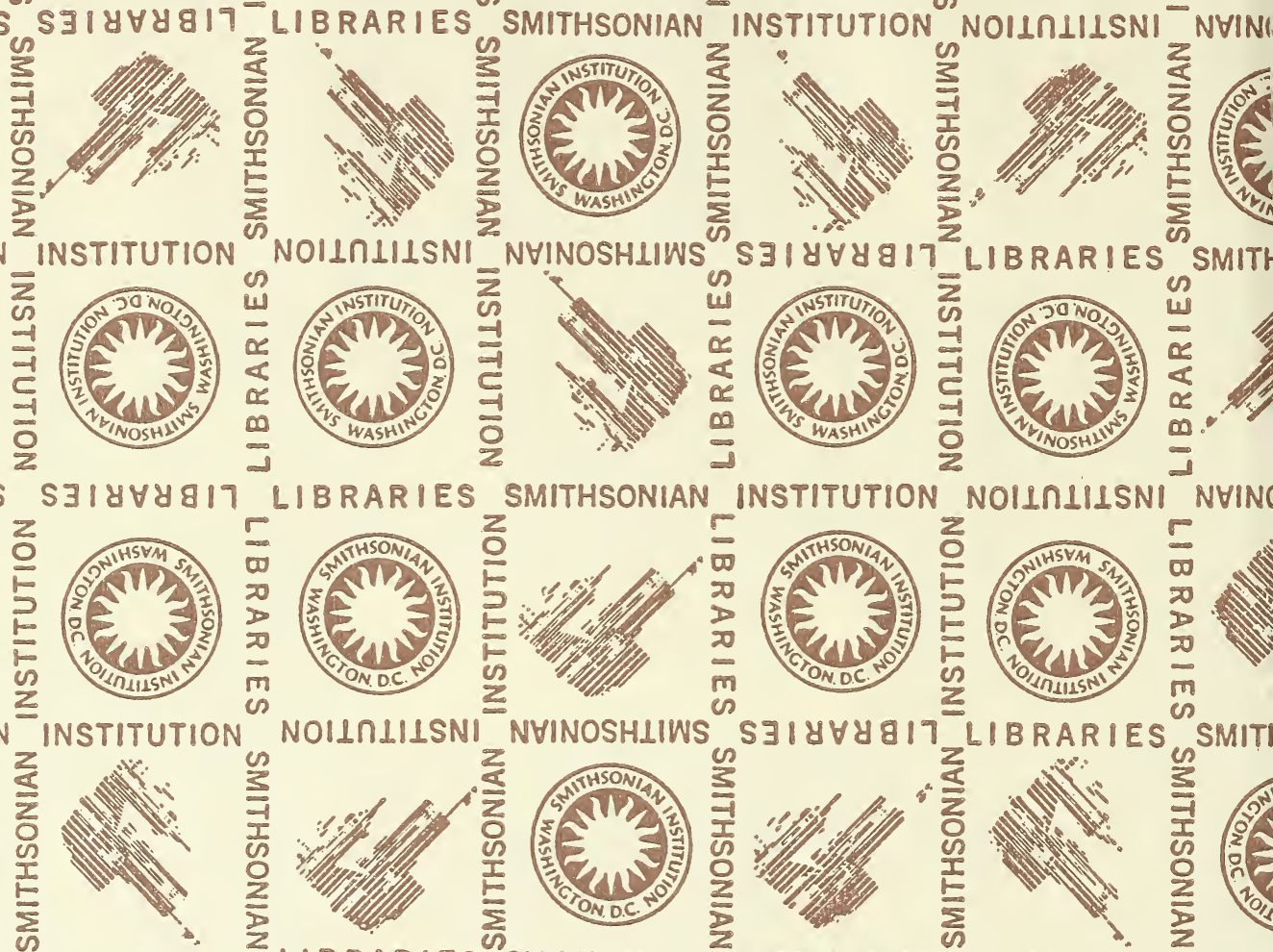

S $\exists I 8 \forall 4817^{\circ}$ LIBRARIES SMITHSONIAN
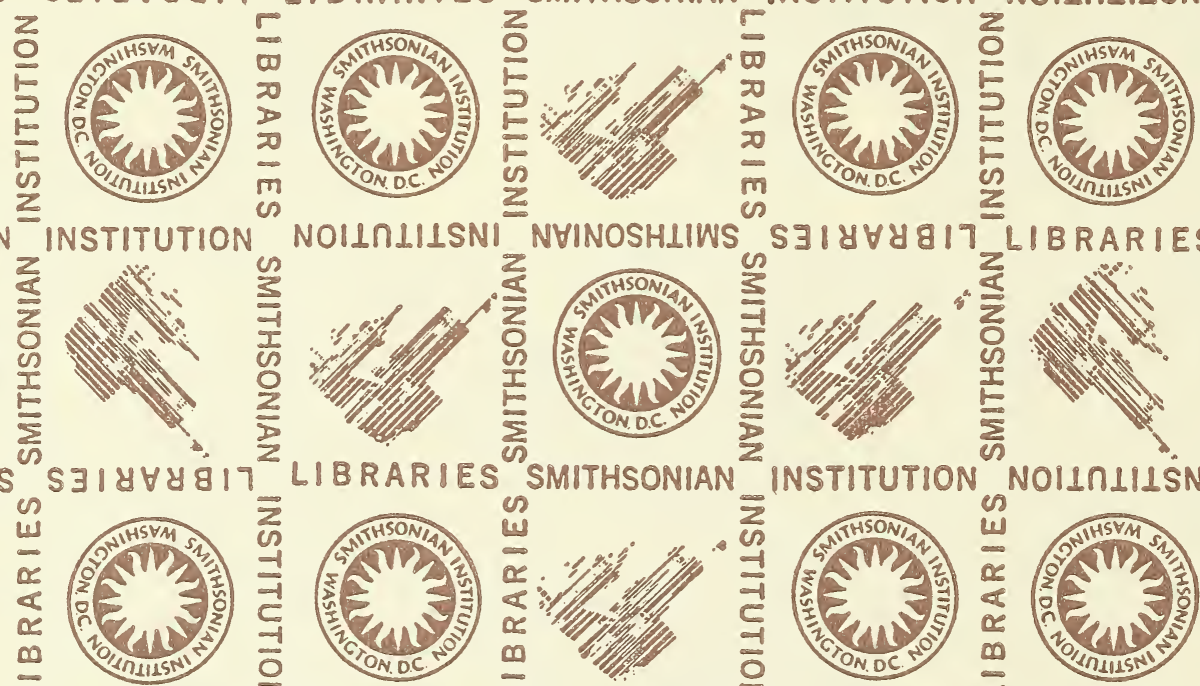

NHINC
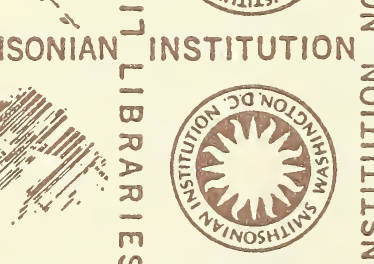

(n)

NOILN1IISNI NHINOSHIIWS
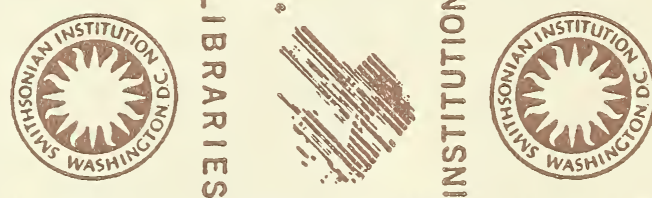

IBRARIES

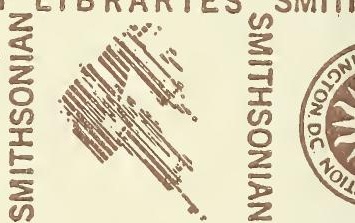

NOIINLIISNI NYINI
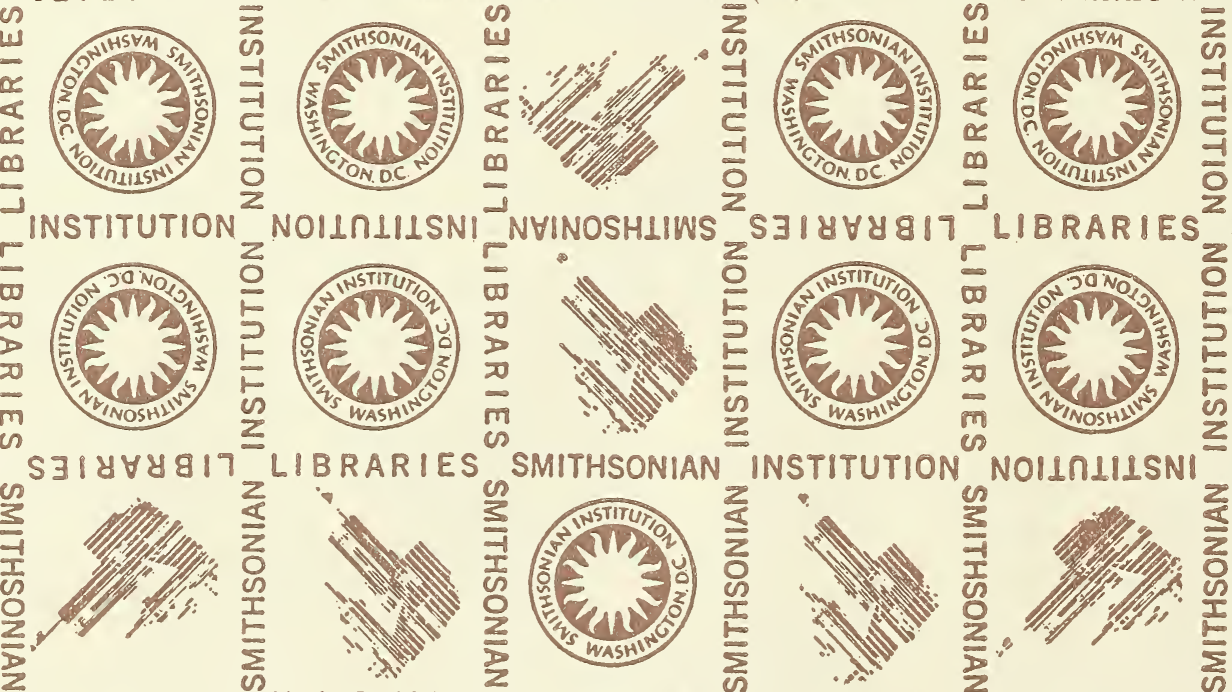

IBRARIES ${ }^{2}$ SMIT

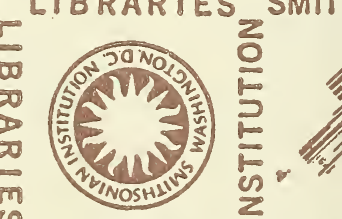

NOHINIISNI NHIN
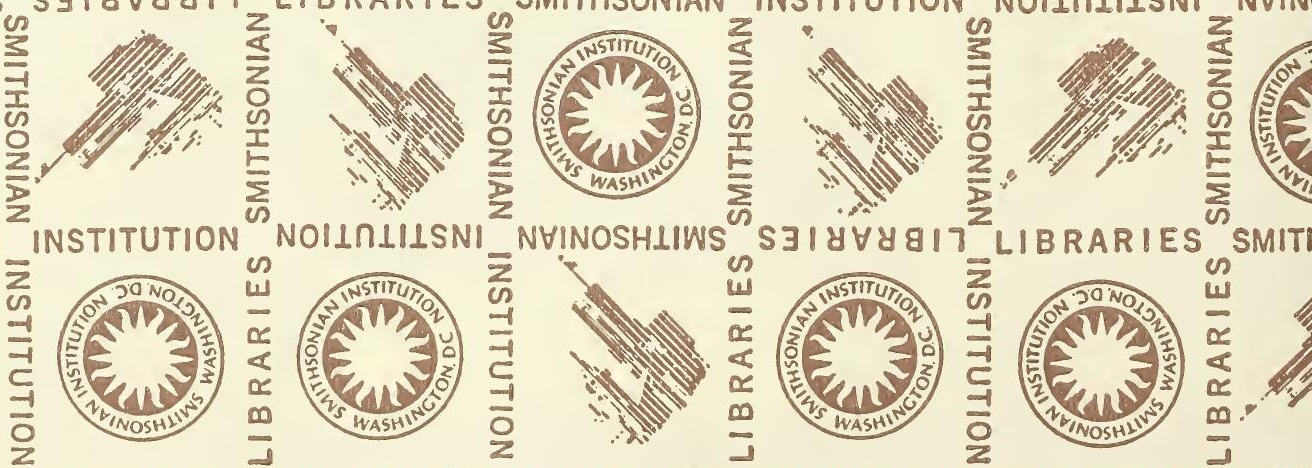

LIBRARIES SMITHSONIAN INSTITUTION NOIINLILSNI NHIN 
